Table 1. Baseline characteristics of Japanese IDDM patients

\begin{tabular}{|c|c|c|c|c|}
\hline Age at onset (years) & $0-5$ & $6-12$ & $13-19$ & $20-$ \\
\hline$n$ & 72 & 171 & 163 & 162 \\
\hline Male/female & $32 / 40$ & $63 / 108$ & $55 / 108$ & $53 / 109$ \\
\hline $\begin{array}{l}\text { Sensory hearing } \\
\text { disturbance }\end{array}$ & 0 & 1 & 0 & 0 \\
\hline Mental retardation & 0 & $1^{\mathrm{a}}$ & 0 & 0 \\
\hline MELAS & 0 & 0 & 0 & 0 \\
\hline Short stature & 2 & 0 & 0 & 0 \\
\hline History of obesity & 0 & 0 & 0 & 0 \\
\hline $\begin{array}{l}\text { History of diabetes in } \\
\text { first-degree relatives }\end{array}$ & $\begin{array}{l}6 \\
(8 \%)\end{array}$ & $\begin{array}{l}15 \\
(9 \%)\end{array}$ & $\begin{array}{l}16 \\
(10 \%)\end{array}$ & $\begin{array}{l}15 \\
(9 \%)\end{array}$ \\
\hline $\begin{array}{l}\text { Coma or ketoacidosis } \\
\text { at diagnosis }\end{array}$ & $\begin{array}{l}65 \\
(90 \%)\end{array}$ & $\begin{array}{l}151 \\
(88 \%)\end{array}$ & $\begin{array}{l}114 \\
(70 \%)\end{array}$ & $\begin{array}{l}111 \\
(69 \%)\end{array}$ \\
\hline 3243 bp mutation & 0 & 0 & 0 & 0 \\
\hline
\end{tabular}

a with Down's syndrome.

MELAS, Mitochondrial encephalomyopathy, lactic acidosis, and stroke-like episodes

strates that the 3243 bp mutation was undetectable in Japanese patients with well-defined IDDM.

Yours sincerely,

Y. Uchigata, M. Mizota, K. Yanagisawa, Y.Nakagawa, T. Otani, H.Ikegami, H. Yamada, J.Miura, T.Ogihara, N. Matsuura, Y.Omori

\section{Molecular mimicry and the T-cell repertoire}

Dear Sir,

We are grateful to Drs. Pujol-Borrell and Pérez de Guzman for their constructively critical comments [1] on our suggestion that molecular mimicry between peptides of, respectively, $\alpha_{2}$ macroglobulin and glutamic acid decarboxylase (GAD) might be implicated in the autoimmune pathogenesis of insulin-dependent diabetes mellitus (IDDM) [2].

These comments require us to be more specific about the current status of our hypothesis on the role of mimicry between ubiquitous internal proteins [3] and tissue-specific autoantigens, which has since become more refined and gained greater credence [4]. We propose that the T-cell repertoire generated in the thymus must be based upon what is available to be presented. The commonest self-peptides eluted from class II-MHC molecules actually derive from class I or II molecules, hence our major interest in "MHC molecular mimicry" [4]. Thus, we believe that the CO4 + T-cell repertoire becomes biased by interaction with class II MHC molecules presenting class-I- or II-derived peptides. This may seem paradoxical in the light of current views on the development of self-tolerance, but it is a pragmatic view of the process of thymic positive and negative selection, and is supported by the fact that it is now recognised that whilst tight binding between $\mathrm{T}$-cell receptor

Corresponding author: Dr. H. Baum, Department of Immunology, King's College School of Medicine and Dentistry, Bessemer Road, London SE5 9PJ, UK

\section{References}

1. Otabe S, Sakura H, Shimokawa K et al. (1994) The high prevalence of diabetic patients with a mutation in the mitochondrial gene in Japan. J Clin Endocrinol Metab 79: 768771

2. Odawara M, Sasaki K, Yamashita K (1995) Prevalence and clinical characterization of Japanese diabetes mellitus with an A-to-G mutation at nucleotide 3243 of the mitochondrial tRNA ${ }^{\text {leu(UUR) }}$ gene. J Clin Endocrinol Metab 80: 1290-1294

3. Oka Y, Katagiri H, Yazaki Y et al. (1993) Mitochondrial gene mutation in islet-cell-antibody-positive patients who were initially non-insulin-dependent diabetics. Lancet 342 : $527-528$

4. Yanagisawa K, Uchigata Y, Sanaka M et al. (1995) Mutation in the mitochondrial tRNAleu at position 3243 and spontaneous abortions in Japanese women attending a clinic for diabetic pregnancies. Diabetologia 38: 809-815

5. Tuomilehto J, Podar T, Tuomilehto-Wolf E (1991) Variation in insulin-dependent diabetes mellitus (IDDM) in Finland and in the Baltic region: a case of genetic-environmental interaction? In: Rifkin JA, Tailor SL (eds) Diabetes 1991. Elsevier, Amsterdam pp 995-1001

6. Goto Y, Nonaka I, Horai S (1990) A mutation in the tRNA leu(UUR) gene associated with the MELAS subgroup of mitochondrial encephalomyopathies. Nature 348: 651-653

and MHC-ligand complex leads to T-cell anergy or apoptosis, weaker binding leads to selection [5].

In the light of these considerations, we return to our original observation of striking similarities between, on the one hand, T-cell epitopes of bacterial and viral immunogens and, on the other, self MHC-derived peptides [3]. Such examples underpin the concept that $T$ cells selected centrally for modest affinity to such latter epitopes might in the periphery have higher affinity, or a qualitatively different reactivity [6] for mimicking epitopes. This establishes a scenario for preferential immunological responsiveness and, under appropriate circumstances, for autoimmune disease.

MHC-derived peptides are not the only peptides presented by antigen-presenting cells (APCs) in association with class II MHC molecules, and a major plasma protein such as a $\alpha_{2}$ macroglobulin is highly likely to be represented in the repertoire of peptides presented by thymic APCs during T-cell ontogeny. So our speculation is that $T$ cells, binding with moderate-low affinity to the GAD-mimicking peptide that we have identified, could be positively selected; the availability of this selected Tcell receptor defines the immunodominant epitope in any subsequent response, for example to infection with coxsackie virus. In that case, the $\mathrm{T}$ cells selected by recognition of the $\mathrm{PE}$ VKSK peptide of $\alpha_{2}$ macroglobulin [2] are stimulated by an APC presenting the PEVKEK sequence of the $\mathrm{P} 2-\mathrm{C}$ replicative complex of coxsackie $B 4$. That response then sets the scene for a mimicry-driven reactivity against the corresponding peptide in GAD.

We are aware that much of this is conjecture, although now based on a growing body of circumstantial evidence. However, we believe that the underlying concept is a fruitful one, ac- 
counting as it does for the selection of a limited number of $\mathrm{T}$ cell epitopes from complex immunogens (e.g. the PEVKEK sequence in the case of coxsackie B4) and for MHC association with autoimmune disease under circumstances where there does not seem to be restricted presentation of relevant $T$-cell epitopes [7].

Yours sincerely,

H. Baum, M.Peakman, M.N.Norazmi, D. Vergani

\section{References}

1. Pujol-Borrell R, Jaraquemada Perez de Guzman D (1995) Reply to Norazmi et al. Diabetologia 38: 875

2. Norazmi MN, Peakman M, Vergani D, Baum H (1995) Shared amino acid sequences between glutamic acid decar- boxylase 65 and 67 and alpha-2-macroglobulin. A focus for cross-reactive autoantibodies? Diabetologia 38: 874-875

3. Baum H, Butler P, Davies H, Sternberg M, Burroughs A (1993) Autoimmune disease and molecular mimicry: an hypothesis. Trends Biochem Sci 18: 140-144

4. Baum H, Brusic V, Choudhuri K, Cunningham P, Vergani D, Peakman M (1995) MHC molecular mimicry in diabetes. Nature Med 1: 388

5. Von Boehmer H (1994) Positive selection of lymphocytes. Cell 76: 219-228

6. Sloan-Lancaster J, Allen PM (1995) Significance of T-cell stimulation by altered peptide ligands in T-cell biology. Curr Opin Immunol 7: 103-109

7. Albani S, Keystone EC, Nelson JL et al. (1995) Positive selection in autoimmunity: abnormal immune responses to a bacterial dna $T$ antigenic determinant in patients with early rheumatoid arthritis. Nature Med 1: 448-452

\section{Diabetes mellitus and Alzheimer's disease: glycation as a biochemical link}

Dear Sir,

Advanced glycation end products (AGE) are a family of complex, evolved post-translational modifications initiated by the condensation of reducing sugars with protein amino groups via the Maillard reaction [1]. Considerable evidence suggests that glycation of proteins and AGE play a role in the pathological processes of diabetes. Recently, several independent investigations have revealed that AGE-relate modifications are also found in Alzheimer's disease, the leading cause of senile dementia [2]. In Alzheimer's disease, the protein components of the pathological lesions (i.e., neurofibrillary tangles and senile plaques) contain AGE modifications and these post-translational events are thought to be involved in the formation of the lesions [3-6]. Additionally, together with evidence of free radical damage in Alzheimer's disease $[2,7,8]$, these findings suggest that, as with diabetes, glycoxidation (i.e., glycation-related oxidative processes) is likely to play a role in the pathogenesis of Alzheimer's disease [2].

The occurrence of AGE modifications in both diabetes and Alzheimer's disease might lead one to predict a higher-thanexpected incidence of concurrent diabetes and Alzheimer's disease. However, predictions of diabetes and concurrent Alzheimer's disease unfortunately must await epidemiological analyses that consider the lowered life expectancy of uncontrolled diabetic patients, in whom glycation is greatest. Conversely, life-long glycation may result in compensations, leading instead to discordance of Alzheimer's disease and diabetes. Obviously, further investigation is essential to bear out either association.

Whether glycation in Alzheimer's disease is a primary or secondary event is controversial [9]. However, the presence of AGE modifications in the earliest pathological changes in Alzheimer's disease indicates that AGE-modification, in synergy with oxidative modifications, are likely early in vivo events $[2,10]$. Indeed, other factors may initiate Alzheimer's disease, predisposing them toward glycoxidative damage, and such an interpretation is attractive when one considers the spo-

Corresponding author: Dr. M. A. Smith, Institute of Pathology, Case Western Reserve University, Cleveland, Ohio 441062622, USA radic onset of most cases and the individual variation that includes mentally normal individuals with abundant senile plaques. Demonstration of links between Alzheimer's disease and metabolic disturbances of glucose metabolism or imbalances in free radical or reactive oxygen species detoxification may clarify these issues. In any event, the commonality of AGE modifications and free radical damage in diabetes and Alzheimer's disease suggests that common therapeutic rationales might be considered.

Yours sincerely,

M. A. Smith, L. M. Sayre, G.Perry

\section{References}

1. Monnier VM, Cerami A (1981) Nonenzymatic browning in vivo: possible process for aging of long-lived proteins. Science 211: 491-493

2. Smith MA, Sayre LM, Monnier VM, Perry G (1995) Radical AGEing in Alzheimer disease. Trends Neurosci 18: 172-176

3. Smith MA, Taneda S, Richey PL et al. (1994) Advanced Maillard reaction products are associated with Alzheimer disease pathology. Proc Natl Acad Sci USA 91: 5710-5714

4. Ledesma MD, Bonay P, Colaco C, Avila J (1994) Analysis of microtubule-associated protein tau glycation in paired helical filaments. J Biol Chem 269: 21614-21619

5. Yan S-D, Chen X, Schmidt A-M et al. (1994) Glycated tau protein in Alzheimer disease: a mechanism for induction of oxidant stress. Proc Natl Acad Sci USA 91: 7787-7791

6. Vitek MP, Bhattacharya K, Glendening JM et al. (1994) Advanced glycation end products contribute to amyloidosis in Alzheimer disease. Proc Natl Acad Sci USA, 91: 4766-4770

7. Smith MA, Kutty RK, Richey PL et al. (1994) Heme oxygenase-1 is associated with the neurofibrillary pathology of Alzheimer disease. Am J Pathol 145: 42-47

8. Pappolla MA, Omar RA, Kim KS, Robakis NK (1992) Immunohistochemical evidence of oxidative stress in Alzheimer's disease. Am J Pathol 140: 621-628

9. Mattson MP, Carney JW, Butterfield DA (1995) A tombstone in Alzheimer's? Nature 373:481

10. Smith MA, Sayre LM, Vitek MP, Monnier VM, Perry G (1995) Early AGEing and Alzheimer's. Nature 374: 316 